Чепурняк T. О. кандидат філологічних наук, асистент Кам'янець-Подільського національного університету імені Івана Огієнка

\title{
ТЕАТРАЛЬНІ РЕЦЕНЗІЇ СТЕПАНА ВАСИЛЬЧЕНКА: ЖАНРОВО-СТИЛЬОВІ ОСОБЛИВОСТІ
}

У статті розглядаються театральні рецензї Степана Васильченка, які були вперше опубліковані на сторінках видання «Рада». Значна увага в дослідженні зосереджена на мові, композиції рецензій, які репрезентують індивідуальний стиль автора, а також на обтрунтуванні Степаном Васильченком мистеиької вартості п'єс, вистав. Автором статті окреслені специифіка процесу рецензування $і$ завдання рецензента.

Ключові слова: рецензування, театральна рецензія, актор, роль, п’єса, вистава, епітет, персоніфікачія, метафора.

В статье рассматриваются театральные рецензии Степана Васильченка, которые были впервые опубликованы на страницах издания «Рада». Значительное внимание в исследовании сосредоточено на языке, композищии рецензий, представляющих индивидуальный стиль автора, а также на обосновании Степаном Васильченком художественной ценности пьес, спектаклей. Автором статьи очерчень специфика процесса реиензирования и задачи рецеензента. 
Ключевые слова: рецензирование, театральная рецензия, актер, роль, пьеса, спектакль, эпитет, персонификачия, метафора.

The article deals with Stepan Vasylchenko's theatrical reviews, which have been first published on the pages of the edition "Rada". In the research considerable attention is focused on the language, compositions of reviews, which represent the individual style of the author, and also on grounding of artistic value of plays, performances by Stepan Vasylchenko. The author of the article outlines the specificity of the review process and reviewer's tasks.

Keywords: reviewing, theatrical review, actor, role, play, performance, epithet, personification, metaphor.

Рецензування - один із методів критики, який передбачає детальне вивчення об’єкта дослідження для визначення його позитивних сторін та недоліків. Появу рецензії зумовлює новий твір, що є явищем певної сфери життя, має художню чи наукову завершеність, цінність. Отримані враження стимулюють фахівця до роздумів над прочитаним, почутим, побаченим. Однією із ключових жанрових ознак $є$ хронологічна актуальність, тому аргументованим є погляд В. Здоровеги, котрий вбачає в рецензії реалізацію інформаційних, а також аналітичних можливостей 3МІ [Здоровега 2004:204], К. Серажим поділяє певною мірою думку науковця й відзначає синтетичний характер жанру [Серажим 2008:315]. Специфіка рецензування виявляється в об’єкті критики, адже це не безпосередні факти дійсності, а інформаційні явища (книги, вистави, фільми) [Тертычный 2010:258], тобто уже відображена кимось реальність. Відтак рецензії дослідники тематично поділяють на літературні, мистецькі, наукові, які мають підвиди [Серажим 2008:314; Кузнецова 2013:106]. Незалежно від об’єкту розгляду основне для журналіста - побачити щось таке, чого не спроможен помітити читач чи глядач.

Щоб бути авторитетною особою для автора артефакту, читачів, рецензент зобов’язаний знати всі нюанси, розкривати суть твору, пам'ятаючи, що це не переказ, а всебічний i об’єктивний аналіз. Рецензент, маючи естетичні принципи, повинен сформувати об'єктивну громадську думку, тому в рецензії, окрім характеристики, наявна й оцінка. Вона грунтується не лише «на об'єктивних судженнях розуму, а й на суб'єктивних підказках почуттів» [Лазутина 2011:226]. О. Чернікова переконана, що об’єктивність у рецензії - це річ умовна, хоча теоретично рецензент повинен прагнути об’єктивної 
характеристики і виваженої оцінки [Черникова 2012:302]. Особливості іï як змістоформи визначає і чітка комунікативна мета - привернути увагу читача, вплинути на нього образним словом.

Рецензії $є$ демонстрацією індивідуальності рецензента. Аргументом цьому слугує діяльність Степана Васильченка. Хоч в історію української літератури він увійшов як новеліст, однак працював і в інших жанрах (п'єси, поезії в прозі, казки, нариси, літературно-критичні та публіцистичні статті, вірші, поеми). Рецензії увійшли до його художньої спадщини, однак не були самостійним об’єктом вивчення. Дослідники згадували рецензії в контексті розгляду творчості письменника, що й зумовлює актуальність дослідження: якщо В. Костюченко обмежується констатацією [Костюченко 1978:32], то В. Курашова конкретизує, вказуючи на їхню тематичну спрямованість театральні рецензії, у яких письменник «підтримував реалістичний напрям української театральної трупи М. К. Садовського»[Курашова 1959:51]. Відтак мета статті - висвітлити специфіку театральних рецензій Степана Васильченка. Мета дослідження передбачає розв’язання комплексу завдань:

- окреслити специфіку процесу рецензування та завдання рецензента;

- розкрити жанрово-стильові особливості театральних рецензій Степана Васильченка, опублікованих на шпальтах газети «Рада»;

Співпрацю 3 українським періодичним виданням «Рада» Степан Васильченко розпочав у 1909 р., надіславши вірш «Коло хати» за підписом С. Панасенко. Згодом, після друку кількох оповідань, одержав запрошення працювати в єдиній на той час наддніпрянській українській газеті, проте не одразу погодився: сподівався отримати посаду вчителя, а лише в разі відмови обіцяв приїхати до Києва, висловлював побоювання, чи зможе вести відділ фейлетонів. Прийняття остаточного рішення Н. Шумило пов’язувала 3 його намірами: надрукувати оповідання, познайомитися 3 людьми, які мають відношення до літератури [Шумило 1986:22]. Однак значну роль в його житті відігравав театр: 3-під його пера 3'являються п’єси, очолює відділ театральної хроніки в газеті «Рада». 321 серпня 1913 р. з’явилися рецензії Степана 
Васильченка під рубрикою «Театр i музика». Автор послуговувався псевдонімом Загородній, а в 1914 р. опублікував рецензію як Танасюк. Вчений О. Тертичний театральну рецензію вважає одним iз найскладніших видів, оскільки розширюється коло завдань рецензента: аналізується робота творчого колективу (усебічний розгляд), а подекуди зіставляється літературне першоджерело 3 інсценуванням [Тертычный 2010:262]. Відтак популяризація досягнень театру, вказівка на недоліки постановки, зокрема гри акторів, режисури - основне призначення театральної рецензії. Рецензент повинен захистити громадськість від бездарного, низькопробного твору, чітко обгрунтовуючи власну оцінку, яка не має бути суб’єктивним свавіллям.

Степан Васильченко зосереджував свою увагу на виставах театральної трупи М. Садовського, зазначаючи про це в заголовках рецензій «Украӥнська трупа М. К. Садовського», «Театр М. К. Садовського», нижче вказував назву п’єси та іï автора. Рецензент вдавався подекуди до зіставлення твору та його сценічного втілення, проводив паралель. До прикладу, драму М. Старицького «Ой не ходи, Грицю, та на вечорниці» визначає як стара, широко відома п’єса. До іiі недоліків зараховує важку композицію, старий сюжет, довгі, малоцікаві монологи. Всупереч цьому, на неї ходить досить публіки. Рецензент прагне 3'ясувати: що є привабливого в п’єсі. Він вважає, що актори, хоч і доклали максимум зусиль, однак подекуди це виглядає як реміснича робота: «Aктори поставились до п’єси цุілком совісно, висмоктали з неї все, щуо можна було висмоктати, але мимоволі після моментів захоплення в грі виглядає зануда» [Васильченко 1960:89]. Степан Васильченко вбачає й позитивні риси: окремі сценки (веселі вечорниці, дівчата на річці з білизною), відповідна декорація, прекрасне виконання народних пісень, які автор іменує перлинами народної творчості і висловлюється про них метафорично: ними «густо вмережано поле n’єси», «ухо чарує рідна мелодія» [Васильченко 1960:90]. Він приходить до висновку: перераховане викликає інтерес i приваблюватиме в майбутньому глядачів у театрі Миколи Садовського. Рецензент не вказує точної дати, коли сам був глядачем, а лише послуговується описовим висловом «позавчорашня 
вистава». Надалі в рецензіях він вказує точну дату постановки.

Щодо доцільності подальшої інсценізації драми «Наталка Полтавка» Степан Васильченко розмірковує в наступній рецензії «Український театр М. К. Садовського», конкретизуючи в підзаголовку «Одкриття зимового сезону». У першому абзаці подано факт із вказівкою на дату (31 серпня розпочато зимовий сезон виставами «Наталка Полтавка», «На перші гулі»), місце (троїцький народний театр), виконавців (трупа М. К. Садовського). Рецензент вдається до аналізу постановки твору I. Котляревського. 3-поміж акторського складу виділяє Садовського (Виборний), Мар'яненка (Микола). Особливу увагу зосереджує на виступі молодої артистки-дебютантки Марії Литвиненко-Вольгемут, яка виконувала роль головної героїні, i образно висловлює думку, використовуючи сплетіння епітетів, метафор, порівняння: «Надзвичайно гарно залунав.. чистий, як щуире срібло, голос Наталки ... іскрами розсипався по найдальнішим куткам театру» [Васильченко 1960:95]. Рецензент називає п’єсу «вічно молодою» й приходить до висновку, що іiі i надалі варто ставити на сцені, наводить аргументи: художня вартість, популярність, постаті, яких можна побачити на теренах України, вплив на народні маси й формування доброти, людяності. Степан Васильченко вади вбачає в «застарілих архаїзмах» (використано тавтологічний зворот), без яких виглядала б п’єса по-сучасному. Відтак рецензію завершує пропозицією: «Не було б гріхом перед автором n'єси і вандалізмом, коли б ту зайву шкаралющу, звичайно, з пильною осторогою, було знято з n’єси» [Васильченко 1960:95].

У наступній рецензї Степан Васильченко зазначає, що вистава «Зачароване коло» відбулася 21 серпня і пройшла, як і в перші рази, з успіхом, конкретизуючи - матеріальним і художнім. Степан Васильченко наголошує на тому, що п’єса перекладна, а сприймається як оригінальна, частіше з’являється в репертуарі трупи Миколи Садовського. Причину цього вбачає в авторі драматичної казки, якого названо лише в підзаголовку. У самій рецензії на позначення Л. Ріделя вжито перифразу «письменник близької нам по мові та звичаям польської народності». На думку рецензента, за художньою 
довершеністю вистава й п’єса однакові: у грі артистів не втрачається глибока думка, дехто зміг утворити оригінальні постаті. 3-поміж них виокремлює «д-ку Долю», використовуючи для характеристики порівняння, метафори, низку епітетів: «На диво тонко $і$ артистично провела роль дурника Марцฺюся, хлопчика із складною психікою та з поетичною душею, $з$ тонким духовним складом в кволому, в шмаття одягненому тілі. Мов яким чаром приковувало до сцени публіку...» [Васильченко 1960:90]. Далі рецензент переказує сцену, яка його найбільше вразила, вказує на недоліки гри партнера в тій дії. Він не впорався належним чином 3 роллю лісового діда: «осуркувато-роблений тон», немов передражнював когось, відсутність спокою, смутку, теплої ласки в окресленій сцені. Л. Кройчик зауважує, що «в театральній рецензії можна лище проаналізувати роботу режисера чи гру одного-двох акторів, але завжди потрібно дати аудиторї иілісне уявлення про твір» [Кройчик 2000:155]. Так чинить і Степан Васильченко. Він відзначає невелику кількість хиб, котрі не вплинули на цілісне враження від вистави, яка вносить нове, корисне в український театр, $є$ свідченням його змін. Не усвідомлення іншими цих нововведень викликає обурення в рецензента, який вдається до використання емоційно забарвленої лексики, помережаної персоніфікаціями та епітетами: «Треба мати немало тупості або бути ціілком засліпленим злістю до українського національного руху, щуоб не бачити, як скидає наш театр із себе стару плісняву шкаралюшу, струшує з плечей ярмаркове баляндрасничання...» [Васильченко 1960:91]. Це, на думку Степана Васильченка, допоможе українському театру досягти рівня театрів країн 3 високорозвиненою культурою.

Однак не всім нововведенням рецензент дає схвальний відгук. У газеті «Рада» за 21 вересня 1913 р. зазначає, що переробка повістей і романів для постановки є небезпечною річчю: можна попсувати літературний твір, адже автор дотримується іншої композиції, тому лише йому вдасться трансформувати оригінал. Такий процес рецензент подає метафорично як вироблення полотна: «Щоб пристосувати роман до сичени, треба увесь 
художній матеріал, з якого його зоткано, розсукати по нитці $і$ переснувати на нове» [Васильченко 1960:97]. Для підтвердження таких тверджень наводиться конкретний приклад - драма на 4 дії М. Старицького (по Гоголю) «Тарас Бульба». Рецензент зазначає: повість не підходить для інсценізації, але не утверджує це за істину, послуговуючись вставною конструкцією «на нашу думку». Тут вже постановка знаходиться на рівень нижче оригіналу i сприймається як ілюстрування художнього твору. Відзначено й позитивні моменти: окремі сцени були тотожні гоголівським за силою (зустріч Бульби 3 синами, ніч під Дубном, смерть Андрія, Бульби), гра акторів, зокрема Миколи Садовського в ролі Бульби й I. Мар'яненка - Андрія. Всупереч цьому рецензент не вважає постановку вдалою з мистецького погляду, у підсумку мовить про матеріальні вигоди й непримхливих глядачів: «Bистави «Тараса Бульби» дають добрі збори... і мають між публікою багато прихильників, як мають своїх прихильників між читачами книги з малюнками» [Васильченко 1960:97].

Побіжний розгляд акторського складу i зосередженість на окремих сценах простежено і в рецензії на виставу «Суєта» трупи Миколи Садовського за 7 вересня 1913 р., в якій охоплено лише сильні сторони: художність, актуальність (відхід інтелігенції від народу), довершене акторське виконання (щирість, правдивість, не шаблонність, а демонстрація оригінальних постатей). Іншу оцінку однойменній виставі, яку представила трупа Світлова, дає Степан Васильченко у газеті «Рада» за 6 березня 1914 р. Серед акторів відзначає Яремченка, Ясинську, Волинського, однак найбільше його вражає гра П. К. Саксаганського, для якої властиві такі риси: «відсутність зайвої шатанини по сцені, штучної жвавості й фальшивої пози», «внутрішнє напруження творчої сили», не крикливі жарти, «блискуча, натуральна вимова української мови». Всупереч цьому приходить до висновку: «П'єса пройшла рівно, хоч трохи мляво. Найкращче місие у 2-ій дї - розлука батьків із сином... почало було навівати публіці відповідний глибоко смутний настрій, але д. Світлов сам зіпсував його немилосердно» [Васильченко 1960:101]. Творче рішення Світлова 
викликає несприйняття в рецензента, емоційний стан якого виражено через фразеологічний вислів «і сміх і гріх», яким завершено оцінку.

У міні-рецензії на п’єсу «Крути, та не перекручуй» М. Старицького Степан Васильченко перелічує молодих акторів i окремо відзначає вдало втілені на сцені ролі, супроводжуючи лаконічними характеристиками: цільно, енергійно (крутій-адвокат), бадьоро, 3 гумором (глухий дід), правдиво й детально (хитрий селянин-глитай), чепурненько, граціозно (дочка і наймичка адвоката). Позитивні сторони акторської гри окреслено і в рецензії на «Дві сім’ї», побутові драматичні малюнки на 4 дії М. Кропивницького, подаючи також реакцію публіки на виставу і простежуючи в цьому вплив українського театру на реципієнтів. Наголошено на складі глядачів - селяни, що мали змогу прийти завдяки зменшеним цінам.

У спадщині Степана Васильченка $є$ присвячені бенефісам акторів рецензії, які цілком протилежні за композицією і тональністю. Так, у рецензії «Бенефіс артиста I. О. Мар'яненка» 3 перших рядків автор намагається з’ясувати, що примусило актора взяти п’єсу із робітничого побуту «Батраки» для свого творчого звіту, яка є переробкою з російського твору. У ній рецензент не вбачає ні цілісності компонентів, ні провідної думки, ні живих типів. П'єса, на думку Степана Васильченка, не дає можливостей для I. Мар’яненка створити на сцені цільну, правдиво змальовану, яскраву центральну постать Юрка. Не оживили п’єсу і плеяда талановитих акторів. Не применшуючи здібностей, вкладу актора у розвиток мистецтва, рецензент передає враження глядачів, наводячи певні докази, сміливо робить припущення: «Публіки в театрі було повно, слухала вона n'єсу вибачливо, добродушно, часто позіхаючи в рукав, і щзиро вітала бенефіціанта й артистів; але цุе, треба думати, свідчило більше про симпатію публіки до бенефіціанта..., а не про задоволення n’єсою» [Васильченко 1960:92]. Степан Васильченко робить кілька зауважень щодо інсценізації власної п’єси «На перші гулі», уникаючи вказівки на своє авторство і висловлюючи пропозиції від імені першої особи множини («маємо подати декілька своїх уваг»): звернути увагу на дівочі переспіви, що утворюють 
певну ілюзію, обережно поставитися до сцени 3 опудалом, виконавцю ролі Савки Д. Мироненку змінити тон«на більш щирий, світлий».

Натомість у рецензії про бенефіс Миколи Садовського спершу з’ясовуються походження сюжету п’єси (взято народну думу про Саву Чалого), відмінності між фольклорним та створеним I. Карпенком-Карим образом: зрадник i жертва обставин, який прагне спокою для свого краю. Після передісторії Степан Васильченко вказує на дату 30 серпня i зауважує, що згадана п’єса була обрана М. К. Садовським для бенефісу. Рецензент не вдається до деталей, характеризуючи акторське виконання, однак не відмовляється від художнього зображення: «Показав нам лицаря-козака із зовнішнього $i$ внутрішнього боку, виявивщи для изього багато тонкої артистичної гри... Притягувала до себе ияя прегарна... постать козака-лицаря, оповитого смутним фльором хоч $i$ не свідомої, але жалюгідної зради» [Васильченко 1960:94]. На відміну від попередньої рецензії, у якій відзначав суцільні недоліки, тут наявні лише схвальні відгуки: п’єса пройшла гармонійно, однак найкращою частиною драматичного твору вважає останню дію. Відзначено велику кількість глядачів, незважаючи на несприятливі погодні умови - дощ. Мовлячи про вшанування Миколи Садовського, у висновках величає його як відомого актора, так і діяча українського театру, усвідомлює труднощі в його праці та висловлює метафорично побажання у формі дієслова першої особи множини: «Побажаємо тільки йому поміж всякими каміннями й тернами щзасливо вести й далі рідний театр по певному шляху» [Васильченко 1960:94]. Корисно було б рецензентові виявити й помилки, оскільки в читача може виникнути сумнів щодо об’єктивності автора.

Розглянувши рецензії Степана Васильченка, виявлено, що тексти зазвичай логічно структуровані, завершені (містять підсумок, оцінку); їм характерна образність (використано метафори, епітети, порівняння, персоніфікації). Рецензент не вдається до переказу драматичного твору, а відзначає у процесі аналізу найбільш вдалі й не вдалі сцени, акторську гру, зіставляє оригінал i виставу, наводячи переконливі аргументи, простежує 
відповідність п’єси потребам дня, висловлює зауваження, пропозиції щодо поліпшення мистецького твору. Образ автора найчастіше прихований за особовим займенником «ми». Степан Васильченко в текстах рецензій уникає вживати ініціали, а розміщує біля прізвищ акторів скорочення д., д-ка добродій, добродійка, однак лише інколи дозволяє собі звернення в такій формі, коли висловлюється про М. К. Садовського, П. К. Саксаганського. Рецензії аргументовані та емоційні, однак подекуди автор не дотримується балансу: або хвалить, що трапляється частіше, або ж критикує. Окреслюючи пізнавальні, естетичні якості вистави, п’єси, дотримується дохідливого, читабельного стилю, що сприяє налагодженню зв'язку з читачем. Театральні рецензії надають допомогу творчим працівникам удосконалюватись, сприяють популяризації мистецтва, формуванню смаків.

\section{БІБЛІОГРАФІЯ}

Васильченко 1960 - Васильченко С. В. Твори : в 4 т./ Степан Васильченко. - К. : Вид-во АН УРСР, 1960. - Т. 4. - 456 с.

Здоровега 2004 - Здоровега В. Й. Теорія і методика журналістської творчості : підручник / В. Й. Здоровега. - Львів: ПАІС, 2004. - 268 с.

Костюченко 1978 - Костюченко В. А. Степан Васильченко. Життя і творчість / В. А. Костюченко. - К. : Дніпро, 1978. - 155 с.

Кройчик 2000 - Кройчик Л. Е. Система журналистских жанров / Л. Е. Кройчик // Основы творческой деятельности журналиста : учебник / [ред. сост. С. Г. Корконосенко]. - СПб. : Знание, 2000. - С. 125-167.

Кузнецова 2013 - Кузнецова О. Д. Аналітичні жанри і методи преси : посібник / Олена Дмитрівна Кузнецова. - Л. : ПАІС, 2013. - 196 с.

Курашова 1959 - Курашова В. Степан Васильченко / В. Курашова // Васильченко С. Твори : в 4 т. / Степан Васильченко. - К. : Вид-во АН УРСР, 1959. - T. 1. - C. 5-55.

Лазутина 2011 - Лазутина Г. В. Жанры журналистского творчества : учеб. пособие / Г. В. Лазутина, С. С. Распопова. - М. : Аспект Пресс, 2011. - 320 с.

Серажим 2008 - Серажим К. С. Текстознавство: підручник / 
К. С. Серажим. - К. : Київський університет, 2008. - 528 с.

Тертычный 2010 - Тертычный А. А. Аналитическая журналистика : учеб. пособие / А. А. Тертычный. - М.: Аспект Пресс, 2010. - 352 с. Черникова 2012 Черникова Е. В. Основы творческой деятельности журналиста : учеб. Пособие / Е. В. Черникова. - 2-е изд., испр. и доп. - М. : Школа издательского и медиа бизнеса, 2012. -414 с.

Шумило 1986 - Шумило Н. М. Проза Степана Васильченка / Н. М. Шумило. - К. : Наукова думка, 1986. - 240 с. 